\title{
HUBUNGAN KOMPOSISI TUBUH DAN STATUS GIZI DENGAN PERKEMBANGAN SEKSUAL PADA REMAJA PUTRI DI PERKOTAAN DAN PERDESAAN
}

\section{(The Association between Body Composition and Nutritional Status with Sexual Development of Adolescents Girls in Urban and Rural Areas)}

\author{
Mega Seasty Handayani ${ }^{*}$, Cesilia Meti Dwiriani² ${ }^{2}$ dan Hadi Riyadi²
}

1PT. Sumber Alfaria Trijaya Tbk, Jl. MH. Thamrin No. 9 Cikokol, Tangerang-Banten 15117

2Departemen Gizi Masyarakat, Fakultas Ekologi Manusia (FEMA), Institut Pertanian Bogor, Bogor 16680

\begin{abstract}
The objective of this study was to analyzed the association of percent body fat and nutritional status on sexual development in adolescence girls in urban and rural areas. A cross sectional study involved 100 students of $8^{\text {th }}$ grade junior high school. Age of menarche and breast growth used as sexual development indicators. Results showed that proportion of subjects with stunting and severe stunting was higher in rural area (34\%) than urban area (14\%). Subjects in urban area had earlier age of menarche (18\%). Breast growth of subjects in urban and rural areas were in midpuberty phase. Statistical analysis showed a correlation between nutritional status (BMI/U) and percent body fat, nutritional status and sexual development, as well as percent body fat and sexual development $(p<0.05)$.
\end{abstract}

Keywords: age of menarche, breast growth, percent body fat

\begin{abstract}
ABSTRAK
Tujuan penelitian ini adalah untuk menganalisis hubungan persen lemak tubuh dan status gizi dengan perkembangan seksual pada remaja putri di perkotaan dan perdesaan. Penelitian ini menggunakan desain cross sectional yang melibatkan 100 siswi kelas VIII SMP. Usia menarche dan pertumbuhan payudara digunakan sebagai indikator perkembangan seksual. Hasil penelitian menunjukkan proporsi subjek pendek dan sangat pendek lebih banyak terdapat di SMP desa (34\%) dibandingkan SMP kota (14\%). Subjek di SMP kota mengalami menarche lebih awal (18\%). Pertumbuhan payudara subjek di SMP kota maupun di SMP desa berada pada fase midpubertas. Hasil analisis statistik menunjukkan terdapat hubungan antara status gizi (IMT/U) dengan persen lemak tubuh, status gizi dengan perkembangan seksual dan persen lemak tubuh dengan perkembangan seksual $(p<0.05)$.
\end{abstract}

Kata kunci: persen lemak tubuh, pertumbuhan payudara, usia menstruasi

"Korespondensi: PT. Sumber Alfaria Trijaya Tbk, Jl. MH. Thamrin No. 9 Cikokol, Tangerang-Banten 15117. Email: megaseasty@gmail.com 


\section{PENDAHULUAN}

Masa remaja merupakan masa perubahan yang dramatis dalam diri seseorang. Menurut World Health Organization (WHO) tahun 2007, remaja adalah anak yang telah mencapai umur 10-19 tahun. Menurut Badan Pusat Statistik (2012), populasi anak remaja di Indonesia mencapai tidak kurang dari 43.6 juta jiwa atau $19.64 \%$. Masa remaja sangat erat kaitannya dengan perkembangan psikis pada periode yang dikenal sebagai pubertas serta diiringi dengan perkembangan seksual. Pubertas terjadi sebagai akibat peningkatan sekresi gonadotropin releasing hormone $(\mathrm{GnRH})$ dari hipotalamus, diikuti oleh sekuens perubahan sistem endokrin yang kompleks yang melibatkan sistem umpan balik negatif dan positif. Selanjutnya, sekuens ini akan diikuti dengan timbulnya tanda-tanda seks sekunder, pacu tumbuh dan kesiapan untuk reproduksi (Batubara 2010).

Tanda pubertas yang umum digunakan pada remaja putri adalah pertumbuhan payudara dan menarche (Parent et al. 2004). Perubahan hormonal akan menyebabkan timbulnya breast budding atau tunas payudara pada usia kira-kira 10 tahun, kemudian secara bertahap payudara berkembang menjadi payudara dewasa pada usia 13-14 tahun. Menarche merupakan menstruasi yang pertama kali dialami wanita. Studi epidemiologis mengungkapkan fenomena yang menunjukkan fakta bahwa usia menarche wanita di berbagai belahan dunia akhirakhir ini semakin cepat. Menurunnya usia waktu menarche sekarang disebabkan oleh keadaan gizi dan kesehatan umum serta status sosial ekonomi yang membaik.

Salah satu parameter antropometri yang juga berpengaruh terhadap pubertas adalah lemak tubuh. Simpanan lemak sangat dibutuhkan untuk perkembangan dan pertumbuhan, salah satunya adalah untuk kematangan seksual. Lemak merupakan salah satu zat gizi yang diperlukan dalam pembentukan hormon seksual seperti estrogen, androgen, dan progesteron. Pada wanita terdapat lemak spesifik yang timbul pada masa pubertas yang merupakan tanda kelamin sekunder yang biasanya ditimbun di payudara, lengan atas, perut bagian bawah, alat genital, dan paha (Widyaningtyas 2013).

Tujuan penelitian ini adalah untuk menganalisis hubungan antara persen lemak tubuh dan status gizi dengan perkembangan seksual pada remaja putri di perkotaan dan perdesaan.

\section{METODE}

\section{Desain, Tempat, dan Waktu}

Desain penelitian yang digunakan dalam penelitian ini adalah cross sectional. Penelitian ini menggunakan data sekunder yaitu sebagian data dari penelitian yang berjudul "Lifestyle and Nutri- tion Aspect of Rural and Urban Adolescents". Penelitian ini dilakukan di empat SMP, yang terdiri dari dua SMP kota dan dua SMP desa yaitu SMP 98 Jakarta, SMP 242 Jakarta, SMP 01 Jasinga dan SMP Giri Taruna Jasinga. Penelitian ini dilakukan pada bulan Februari-Mei 2013.

\section{Jumlah dan Cara Penarikan Subjek}

Populasi penelitian ini remaja putri berusia 13-15 tahun yang didapatkan dari siswi kelas VIII di SMP kota dan SMP desa. Subjek pada penelitian ini berjumlah 100 remaja putri kelas VIII dari setiap sekolah sebanyak 25 orang. Metode yang digunakan dalam penarikan subjek adalah Cluster Random Sampling.

\section{Jenis dan Cara Pengumpulan Data}

Data yang digunakan meliputi Usia menarche dan pertumbuhan payudara diperoleh dengan wawancara langsung dengan alat bantu kuesioner. Data status gizi meliputi berat badan, tinggi badan dan data persen lemak tubuh diperoleh melalui pengukuran secara langsung dengan menggunakan alat Body Fat Monitoring (Omron).

\section{Pengolahan dan Analisis Data}

Penilaian status gizi dilakukan dengan metode antropometri melalui pengukuran berat badan dan tinggi badan. Hasil pengukuran berat badan dan tinggi badan diolah menggunakan WHO Anthroplus untuk menentukan nilai Z-score IMT/U dan TB/U berdasarkan WHO (2007). Kategori status gizi berdasarkan IMT/U dibagi menjadi lima, yaitu obes (>3), overweight (>2 s/d 3), normal ( $-2 \mathrm{~s} / \mathrm{d} 2$ ), kurus $(-3 \mathrm{~s} / \mathrm{d}-2)$, dan sangat kurus $(<-3)$. Kategori status gizi berdasarkan TB/U dibagi menjadi tiga kelompok, yaitu sangat pendek (<-3 SD), pendek $(-3 \mathrm{SD} \leq$ z-score <-2 SD) dan normal ( $\geq-2$ SD). Selanjutnya, hasil pengukuran persen lemak tubuh dikelompokkan menjadi lima kategori berdasarkan cut off point menurut Gibson (2005), yaitu underfat (<13\%), healthy (13-23\%), low risk obese (24-27\%), overfat $(28-32 \%)$, dan obese $(\geq 33 \%)$. Untuk persen lemak tubuh yang diukur dengan menggunakan teknik skinfold digunakan persamaan regresi untuk menduga densitas tubuh anak dengan rumus Durnin \& Womersley (1974).

Usia menarche dikategorikan menjadi tiga yaitu lebih awal (<12.62 tahun), normal (12.6214.01 tahun), dan lambat (>14.01 tahun) (Ulinnuha 2008). Tingkat kematangan seksual menggunakan skala gambar pengamatan tahap perkembangan payudara yang dikembangkan oleh Tanner (Marshall \& Tanner 1969). Perkembangan payudara perempuan dikelompokkan ke dalam tiga tahapan yaitu prapubertas (stadium 1), midpubertas (stadium 2 sampai stadium 4), dan pubertas matang atau dewasa (stadium 5) (Hoffman et al. 2006). 
Analisis data menggunakan uji statistik deskriptif dan inferensia. Uji deskriptif digunakan untuk mendeskripsikan variabel menggunakan distribusi frekuensi dan uji inferensia digunakan untuk mengetahui hubungan antar variabel. Dalam penelitian ini digunakan uji normalitas Kolmogorov Smirnov dan uji beda dengan Independent Sample ttest dan Mann-Whitney. Analisis statistik uji korelasi Pearson dan Spearman digunakan untuk mengetahui hubungan antara persen lemak tubuh dan status gizi dengan perkembangan seksual subjek.

\section{HASIL DAN PEMBAHASAN}

\section{Status Gizi}

Status gizi subjek dihitung menurut Indeks Massa Tubuh menurut Umur (IMT/U) dan Tinggi Badan menurut Umur (TB/U). Status gizi subjek yang diukur berdasarkan IMT/U diperoleh bahwa sebagian besar subjek di SMP kota termasuk dalam kategori normal (76\%), sedangkan yang lainnya tergolong overweight (24\%). Subjek di SMP desa sebagian besar tergolong dalam kategori normal (92\%), sedangkan 6\% subjek kurus dan 2\% lainnya tergolong dalam kategori overweight. Tidak terdapat perbedaan yang nyata antara status gizi (IMT/U) subjek di SMP kota dan SMP desa. Sebagian besar subjek memiliki status gizi baik. Status gizi yang baik akan membuat pertumbuhan seorang remaja menjadi sesuai dengan yang seharusnya karena untuk pertumbuhan yang normal tubuh memerlukan gizi yang memadai (Soetjiningsih 2007).

Status gizi subjek di SMP kota menurut TB/U sebagian besar tergolong dalam kategori normal (86\%), sedangkan $14 \%$ lainnya tergolong dalam kategori pendek. Subjek di SMP desa sebagian besar tergolong dalam kategori normal (66\%), sedangkan $30 \%$ subjek tergolong pendek dan masih terdapat 4\% lainnya yang tergolong dalam kategori sangat pendek, hampir tiga kali lebih besar dibandingkan subjek di kota. Hasil uji beda menggunakan independent sample t-test menunjukkan terdapat perbedaan yang nyata antara status gizi (TB/U) subjek di SMP kota dan SMP desa. Pemenuhan gizi yang baik pada anak akan berdampak pada perkembangan pubertal di masa remaja.

\section{Persen Lemak Tubuh}

Persen lemak tubuh subjek di SMP kota sebagian besar termasuk dalam kategori normal
(46\%), begitu juga dengan subjek di SMP Desa (44\%). Di SMP desa maupun kota sudah menunjukkan risiko persen lemak yang melebihi normal yang ditandai dengan cukup tingginya persen lemak dalam kategori low risk pada subjek di SMP desa yaitu sebesar 32\% dan cukup tingginya persen lemak dalam kategori overfat pada subjek di SMP kota yaitu sebesar 30\%. Rata-rata persen lemak tubuh subjek di SMP desa $23.14 \pm 4.74$ sedangkan rata-rata persen lemak tubuh subjek di SMP kota 24.00 \pm 5.28 . Tidak terdapat perbedaan yang nyata antara persen lemak tubuh yang diukur dengan menggunakan Omron pada subjek di SMP kota dan SMP desa.

\section{Perkembangan Seksual}

Usia menarche. Kisaran usia menarche subjek di SMP kota yaitu 10-14 tahun dengan median 12 tahun. Kisaran usia menarche subjek di SMP desa yaitu 12-15 tahun dengan median 13 tahun. Tabel 1 menunjukkan bahwa $82 \%$ subjek di SMP kota dan 98\% subjek di SMP desa mengalami menarche pada usia 12-14 tahun yang tergolong normal (Ulinnuha 2008). Subjek lainnya di SMP kota (18\%) mengalami menarche lebih awal pada usia 10-11 tahun. Sebanyak $2 \%$ subjek di SMP desa mengalami menarche pada usia 15 tahun dan tergolong menarche lambat.

Menurut Acharya et al. (2006), perbaikan gizi akan berdampak pada penurunan usia menarche. Menarche dini cenderung ditemui pada wanita dengan status gizi yang baik karena status gizi memengaruhi maturitas sistem endokrin. Terdapat perbedaan yang nyata antara usia menarche subjek di SMP kota dan SMP desa.

Pertumbuhan payudara. Pada remaja putri pertumbuhan fisik pada awalnya berupa payudara membesar atau rambut kemaluan mulai tumbuh. Tanner membuat klasifikasi Tingkat Kematangan Seksual (TKS) remaja dalam lima stadium berdasarkan pertumbuhan rambut pubis dan payudara.

Tabel 2 menunjukkan bahwa subjek di SMP kota berada pada fase midpubertas yang ditandai dengan pertumbuhan payudara berada pada kisaran stadium 2-4 sedangkan subjek di SMP desa sebanyak $92 \%$ berada pada fase midpubertas, $4 \%$ pada fase prapubertas dan $4 \%$ pada fase pubertas matang. Berdasarkan hasil penelitian, kisaran pertumbuhan payudara subjek di SMP kota adalah stadium 3. Persentase usia terbesar pada stadium 3 adalah 13 tahun. Hal ini disebabkan oleh perkembangan

Tabel 1. Sebaran Subjek berdasarkan Usia Menarche di Kota dan di Desa

\begin{tabular}{cccccccc}
\hline \multirow{2}{*}{ Usia (Tahun) } & \multicolumn{2}{c}{ SMP Desa } & \multicolumn{3}{c}{ SMP Kota } & \multicolumn{3}{c}{ Total } & \multirow{2}{*}{ Uji Beda } \\
\cline { 2 - 6 } & $\mathbf{n}$ & $\%$ & $\mathbf{n}$ & $\%$ & $\mathbf{n}$ & $\%$ & \\
\hline 10 & 0 & 0 & 1 & 2 & 1 & 1 & \\
11 & 0 & 0 & 8 & 16 & 8 & 8 & \\
12 & 14 & 28 & 21 & 42 & 35 & 35 & \multirow{2}{*}{$\mathrm{p}=0.001$} \\
13 & 22 & 44 & 13 & 26 & 35 & 35 & \\
14 & 13 & 26 & 7 & 14 & 20 & 20 & \\
15 & 1 & 2 & 0 & 0 & 1 & 1 & \\
\hline
\end{tabular}

JGP, Volume 8, Nomor 3, November 2013 
Tabel 2. Sebaran Subjek berdasarkan Pertumbuhan Payudara

\begin{tabular}{|c|c|c|c|c|c|c|c|}
\hline \multirow{2}{*}{ Stadium } & \multicolumn{2}{|c|}{ SMP Desa } & \multicolumn{2}{|c|}{ SMP Kota } & \multicolumn{2}{|c|}{ Total } & \multirow{2}{*}{ Uji Beda } \\
\hline & $\mathrm{n}$ & $\%$ & $n$ & $\%$ & $\mathrm{n}$ & $\%$ & \\
\hline 1 & 2 & 4 & 0 & 0 & 2 & 2 & \\
\hline 2 & 9 & 18 & 6 & 12 & 15 & 15 & \\
\hline 3 & 33 & 66 & 27 & 54 & 60 & 60 & $p=0.014$ \\
\hline 4 & 4 & 8 & 17 & 34 & 21 & 21 & \\
\hline 5 & 2 & 4 & 0 & 0 & 2 & 2 & \\
\hline
\end{tabular}

dari sel lemak dan jaringan penghubung lainnya (Hoffmann et al. 2006). Terdapat perbedaan yang nyata antara pertumbuhan payudara subjek di SMP kota dan SMP desa.

\section{Hubungan Status Gizi dengan Persen Lemak Tu-} buh.

Terdapat hubungan yang signifikan antara status gizi berdasarkan IMT/U dengan persen lemak tubuh $(\mathrm{p}<0.05)$. Acharya (2006) menyatakan bahwa IMT merupakan metode pengukuran antropometri yang dapat memberikan gambaran penilaian lemak tubuh pada remaja, lemak sangat berhubungan dengan Indeks Massa Tubuh (IMT) karena tingginya IMT mengindikasikan lemak tubuh yang lebih tinggi. Namun tidak terdapat hubungan yang signifikan antara status gizi berdasarkan TB/U dengan persen lemak tubuh $(p>0.05)$. Hal ini diduga karena Tinggi Badan menurut Umur lebih mengindikasikan pertumbuhan skeletal berbeda halnya dengan Indeks Massa Tubuh yang memang berkaitan dengan berat badan yang langsung berhubungan dengan lemak tubuh.

\section{Hubungan Status Gizi dengan Perkembangan Sek-} sual.

Terdapat hubungan negatif antara status gizi berdasarkan IMT/U dengan usia menarche $(\mathrm{p}=0.013$; $r=-0.246$ ). Hal ini menunjukkan bahwa semakin tinggi IMT maka usia menarche cenderung lebih dini. Hasil penelitian ini mendukung pernyataan Lusiana dan Dwiriani (2007) yang menyatakan bahwa status gizi memiliki hubungan yang nyata negatif dengan usia menarche. Artinya semakin baik status gizi (nilai IMT/U yang tinggi) maka semakin dini usia menarche.

Menurut Kusuma (2013), gizi kurang selain akan memengaruhi pertumbuhan, fungsi organ tubuh, juga menyebabkan terganggunya fungsi reproduksi. Hal ini akan berdampak pada siklus awal menstruasi, tetapi akan membaik bila asupan gizinya baik.

Terdapat hubungan yang signifikan antara status gizi berdasarkan IMT/U dengan pertumbuhan payudara $(p<0.05)$. Hal ini sesuai dengan penelitian Hoffman et al.(2006) yang menyatakan bahwa perkembangan payudara berhubungan dengan peningkatan nilai IMT pada setiap kelompok usia. Gizi dapat memengaruhi hormon yang merupakan penggerak utama kematangan seksual. Menurut Tena-Sempere (2006) menyatakan bahwa status gizi berhubungan dengan keadaan lemak dalam tubuh. Jaringan lemak yang cukup memengaruhi kadar estrogen non gonad dan menstimulasi gonadotropin releasing hormon $(\mathrm{GnRH})$ dan pertumbuhan payudara merupakan respon terhadap estrogen, yang disekresi oleh folikel yang berkembang di dalam ovarium.

Terdapat hubungan negatif antara status gizi berdasarkan TB/U dengan usia menarche $(p=0.017$; $r=-0.237)$. Hal ini menunjukkan bahwa semakin tinggi tubuh remaja putri maka usia menarche cenderung lebih dini. Frisch dan Revelle (1971) mendapatkan survei bahwa 3 atau 4 bulan per dekade di Eropa dalam kurun waktu 100 tahun terjadi penurunan usia menarche dalam hubungannya terhadap tinggi dan berat badan. Oleh karena itu, terjadinya menarche juga ditentukan oleh tinggi badan tertentu dengan berat badan tertentu karena saat tersebut adalah terjadinya kecepatan metabolik kritis.

Terdapat hubungan yang signifikan antara status gizi berdasarkan TB/U dengan pertumbuhan payudara $(p<0.05)$. Pertumbuhan payudara merupakan awal pertumbuhan fisik remaja putri yang merupakan salah satu penanda pubertas pada remaja. Pemenuhan gizi yang baik pada anak akan berdampak pada perkembangan pubertas di masa remaja. Hal ini sejalan dengan hasil penelitian Buyken et al. (2009) bahwa komposisi tubuh prapubertas pada anak laki-laki dan perempuan yang sehat mempunyai efek terhadap kemajuan perkembangan pubertas.

\section{Hubungan Persen Lemak Tubuh dengan Perkem- bangan Seksual.}

Terdapat hubungan negatif antara persen lemak tubuh dengan usia menarche $(p=0.027 ; r=-$ 0.221). Hal ini menunjukkan bahwa semakin tinggi persen lemak tubuh maka usia menarche cenderung lebih dini. Hal ini mendukung pernyataan Lassek dan Gaulin (2007), bahwa usia menarche berhubungan dengan tingginya proporsi lemak tubuh. Berek dan Novak (2007) menyatakan bahwa anak perempuan harus memiliki berat badan $47.8 \mathrm{~kg}$ sebelum mengalami menarche, yang lebih penting lemak tubuh harus meningkat hingga $23.5 \%$ dari $16 \%$ pada masa prapubertas yang diduga dipengaruhi oleh status gizi. Terjadinya menarche jika persentase lemak tubuh anak sudah mencapai $27 \%$.

Secara fisiologis, lemak akan dipecah menjadi asam lemak dan gliserol. Gliserol larut dalam air se- 
hingga mudah diserap sedangkan di dalam dinding usus, asam lemak disintesa menjadi lemak kembali dan butir-butir lemak sebagai chylomicron dialirkan melalui kapiler lymphe ke dalam ductus thorasicus dan masuk ke aliran darah di dalam angulus venosus. Chylomicron dialirkan oleh darah, dibawa ke hati dan sebagian diambil oleh sel-sel hati untuk mengalami metabolisme lebih lanjut. Sedangkan yang tidak diambil oleh sel hati terus mengalir di dalam saluran darah untuk kemudian diambil oleh sel-sel di dalam jaringan terutama sel-sel lemak di tempat penimbunan.

Di dalam sel jaringan, lemak mengalami hidrolisa untuk menghasilkan energi. Gliserol masuk ke dalam jalur Embden-Meyerhof dari metabolisme karbohidrat dan asam lemak dipecah, setiap kali melepaskan satuan yang terdiri dari dua karbon yaitu acetyl-coa. Acetyl Co-A merupakan bahan bakar yang masuk ke dalam siklus Krebs untuk dioksidasi menjadi $\mathrm{CO}_{2}$ dan $\mathrm{H}_{2} \mathrm{O}$ sambil menghasilkan ATP. Acetyl Co-A ini juga merupakan bahan untuk biosintesis kolesterol yang berpengaruh pada sekresi hormon-hormon, termasuk leptin. Leptin memicu pengeluaran Gonadotropin Releasing Hormone (GnRH) dan selanjutnya memicu pengeluaran Follicle Stimulating Hormone (FSH) dan Luteinizing Hormone (LH) di ovarium sehingga terjadi pematangan folikel dan pembentukan estrogen. Semakin tinggi kadar leptin maka semakin cepat terjadi menarche (Badziad 2003).

Terdapat hubungan yang signifikan antara persen lemak tubuh dengan pertumbuhan payudara $(p=0.003 ; r=0.290)$. Menurut Hoffman et al. (2006) menyatakan bahwa perkembangan payudara perempuan sangat cepat ketika memasuki fase pubertas. Hal ini disebabkan oleh perkembangan dari sel lemak dan jaringan penghubung lainnya. Pada saat pubertas, peningkatan berat badan mencapai $36.5 \%$ kemudian peningkatannya menurun pada tahap selanjutnya yaitu sebesar $8.2 \%$. Peningkatan berat badan disebabkan oleh hormon estrogen yang kemudian mendukung penyimpanan lemak subkutan di payudara.

\section{KESIMPULAN}

Persen lemak tubuh subjek baik di SMP kota maupun di SMP desa sebagian besar normal namun baik di desa maupun di kota sudah menunjukkan risiko lemak tubuh yang melebihi normal yang ditandai dengan cukup tingginya status low risk pada subjek di SMP desa dan cukup tingginya status overfat pada subjek di SMP kota.

Status gizi subjek berdasarkan IMT/U baik di SMP kota maupun di SMP desa sebagian besar normal namun hampir seperempat subjek di SMP kota sudah berstatus gizi overweight. Status gizi subjek berdasarkan TB/U sebagian besar normal namun sub- jek yang berstatus gizi pendek dan sangat pendek di desa hampir tiga kali lebih banyak dibandingkan dengan subjek di SMP kota.

Perkembangan seksual dalam penelitian ini ditandai dengan usia menarche dan pertumbuhan payudara. Usia menarche subjek di SMP kota lebih awal dibandingkan dengan subjek di SMP desa. Median pertumbuhan payudara subjek di SMP kota mupun di SMP desa telah mencapai stadium 3.

Hubungan status gizi dengan persen lemak tubuh menunjukkan bahwa semakin tinggi IMT/U mengindikasikan persen lemak tubuh yang tinggi. Selain itu, semakin tinggi IMT/U, TB/U, dan persen lemak tubuh maka usia menarche semakin dini. Selain itu, IMT/U, TB/U, dan persen lemak tubuh juga berhubungan dengan pertumbuhan payudara $(p<0.05)$.

Penelitian selanjutnya sebaiknya mengkaji faktor-faktor lain yang diduga juga berhubungan dengan usia menarche, antara lain usia menarche ibu, sosial ekonomi keluarga, keterpaparan media massa, aktivitas olahraga, kesehatan, dan lain lain. Remaja putri diharapkan memiliki persen lemak tubuh yang cukup dan menjaga berat badan ideal agar tercapai waktu pubertas yang normal karena pubertas yang datang lebih awal maupun terlambat akan menimbulkan dampak yang cenderung negatif. Gizi merupakan faktor yang sangat memengaruhi pubertas remaja sehingga orangtua diharapkan dapat mempersiapkan kualitas dan kuantitas pangan sejak dini yang baik untuk bekal di saat memasuki masa pubertas.

\section{UCAPAN TERIMA KASIH}

Terima kasih disampaikan kepada Prof. Dr. Ir. Ali Khomsan, MS, Prof. Dr. Ir. Faisal Anwar, MS, dan Mira Dewi, S.Ked, MSi anggota tim peneliti "Lifestyle and Nutrition Aspect of Rural and Urban Adolescents" yang telah mengizinkan penulis menggunakan sebagian data penelitian untuk penulisan makalah ini.

\section{DAFTAR PUSTAKA}

Acharya AVP, Reddaiah N, \& Baridalyne. 2006. Nutritional status and menarche in adolescent girls in an urban resettlement colony of South Delhi. Indian Journal of Community Medicine, $31,4$.

Batubara JRL. 2010. Adolescent development (perkembangan remaja). Sari Pediatri, 12, 1.

[BPS] Badan Pusat Statistik Jawa Barat. 2012. Tingkat kemiskinan Jawa Barat Maret. http: / / jabar.bps.go.id.[diakses 17 Juli 2013]

Buyken AE, Karaolis-Danckert N, \& Remer T. 2009. Association of prepubertal body composition in healthy girls and boys with the timing 
of early and late pubertal markers. The American Journal of Clinical Nutrition, 89, 22-30.

Durnin JVGA \& Womersley J.1974. Body fat assessed from the total body density and its estimation from skinfold thickness: measurements on 481 men and women aged from 16 to 72 years. British Journal of Nutrition, (32), 7797.

Frisch RE \& Revelle R. 1971. Height and weight at menarche and a hypothesis of menarche. Arch Dis Child, 695-701.

Gibson RS. 2005. Principles of Nutritional Assessment. Oxford University Press, New York.

Hoffman WH, Barbeau P, Litaker MS, Johnson MH, Howe CA, \& Gutin B. 2006. Tanner staging of secondary sexual characteristics and body composition, blood plessure and insulin in black girls. Obes Res, 13, 2195-2201.

Kusuma DA. 2013. Hubungan beberapa faktor siswi dengan kejadian menarche pada remaja awal di SMPN 11 Kota Semarang bulan Juni-Agustus 2012. Jurnal Kesehatan Masyarakat, 2(1), $1-10$.

Lassek WD \& Gaulin SJC. 2007. Menarche is related to fat distribution. Am J Phys Anthropol, 133, 1147-1151.
Lusiana SA \& Dwiriani CM. 2007. Usia menarche, konsumsi pangan, dan status gizi anak perempuan sekolah dasar di Bogor. Jurnal gizi dan pangan, 2(3), 26-35.

Marshall WA \& Tanner JM. 1969. Variations in pattern of pubertal changes in girls. Arch Dis Childh, 44, 291.

Parent AS, Teilmann G, Juul A, Skakkebaek NE, Toppari J, \& Bourguignon JP. 2004. The timing of normal puberty and the age limits of sexual precocity: variations around the world, secular trends, and changes after migration. Endo Jnls, 24(5), 668-693.

Soetjiningsih. 2007. Tumbuh Kembang Remaja dan Permasalahannya. Sagung Seto, Jakarta.

Tena-Sempere M. 2006. KiSS-1 and reproduction: focus on its role in the metabolic regulation of fertility. Neuroendocrinology, 83, 275-81.

Ulinnuha DF. 2008. Usia menarke dan perkembangan payudara perempuan di pedesaan Kabupaten Pekalongan [skripsi]. Departemen Biologi, Fakultas Matematika dan Ilmu Pengetahuan Alam, Institut Pertanian Bogor, Bogor.

Widyaningtyas SA. 2013. Hubungan usia menarche dengan obesitas pada remaja putri di SMA Theresiana 1 Semarang. Journal of Nutritional College, 2, 10-17. 